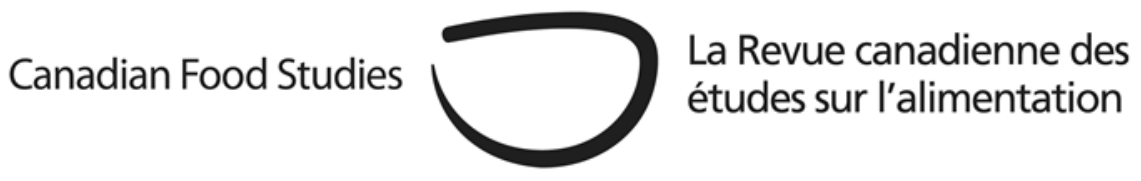

Perspective

\title{
Linking fisheries policy to sustainable diets: The case of Lake Superior
}

Kristen Lowitt ${ }^{a^{*}}$

${ }^{a}$ Queens University

\section{Abstract}

The contribution of fisheries to food systems are largely absent from conceptions of sustainable food systems. At the root of this problem is that fisheries are often seen in terms of maximizing economic efficiency rather than local food security. This perspective piece engages with sustainable diets as a framework for linking fisheries policy with broader food systems considerations asking, how would fisheries policy be different if fisheries were governed with sustainable diets in mind? My discussion is oriented around the case of Lake Superior, the largest freshwater lake in the world and home to commercial, recreational, and Indigenous fisheries. I review the key policies and legislative frameworks influencing the region's fisheries from a sustainable diet lens to put forward some recommendations for how policy change in support of sustainable diets may be fostered.

Keywords: Small-scale fisheries; food policy 
Introduction

Small-scale fisheries play a vital role in the cultures, health, and livelihoods of fishing-dependent communities around the world, including Global North contexts (FAO, 2015; Loring et al., 2013; Lowitt, 2013). Nonetheless, within the sustainable food systems literature, the contribution of fisheries are often overlooked. As Seto \& Fiorella (2017) write, "resources that originate in our oceans, rivers, and lakes are almost entirely omitted in our conceptions of a sustainable food system" (p. 1). In Canada, this is evident in the new Food Policy for Canada. While this Policy recognizes the need for a more integrated approach to food systems, it remains very agriculture centered, as seen in the tag line "a strong agriculture and agri-food sector contributes to economic growth, better nutrition and improved lives for families." At the root of this problem is that fisheries are often seen in terms of maximizing economic efficiency rather than local food security (Fisher et al., 2017; Love et al., 2017). This "resourcist" view (Berkes, 2010) privileges the interests of industrialized, large-scale fleets over those of small-scale harvesters that contribute directly to community well-being, including food needs (Loring et al., 2019). A similar trend is seen in agricultural systems (Hendrickson, 2014; Clapp, 2018). The Good Food Principles emerging from the scholarship and practice of the FLEdGE research team are as relevant to small-scale fisheries as the agricultural sector. The Good Food Principles emphasizing ecological diversity, regional economies, and food as a connector of people and communities may help re-envision the way fisheries are typically understood by shifting the perspective from fish as a commodity towards fish as a part of place-based, sustainable food systems.

This paper engages with the specific framework of sustainable diets as a way of linking fisheries policy and food systems considerations, asking, how may fisheries policy be different if fisheries were governed with sustainable diets in mind? I orient my discussion around the case of Lake Superior, the largest freshwater lake in the world and home to commercial, Indigenous, and recreational fisheries. Adopting a sustainable diets lens, I analyze the key policies and legislative frameworks influencing the region's fisheries to consider how policy change in support of sustainable diets may be fostered.

\section{Sustainable diets}

Sustainable diets seek to link biodiversity with human health and nutrition outcomes; the concept is based in the fundamental premise that the health of people cannot be isolated from the health of ecosystems. The 2010 FAO Biodiversity and Sustainable Diets symposium defines sustainable diets as, "...those diets with low environmental impacts which contribute to food and nutrition security and to healthy life for present and future generations. 
Sustainable diets are protective and respectful of biodiversity and ecosystems, culturally acceptable, accessible, economically fair and affordable; nutritionally adequate, safe and healthy; while optimizing natural and human resources" (Burlingame, Derini, \& FAO, 2010).

The Western diet that has spread around the world has been widely critiqued for initiating and perpetuating diet-related diseases, environmental degradation, and poor outcomes for livelihoods in the food system (Hawkes et al., 2012). This has spurred efforts towards sustainable diets that are more diverse and based in regional biodiversity and socio-cultural contexts (Burlingame, Derini, \& FAO, 2010). In the case of fisheries, this will require adjustments in fish consumption in different regions to correspond with the health and state of fish stocks. The concept of sustainable diets is based in a food systems perspective which recognizes that the harvesting, production, processing, retail, consumption and waste of food, along with associated policies and decision-making structures, interact to shape ecological and human health outcomes (Tansey \& Worsley, 1995).

Achieving sustainable diets depends on supportive policy and governance. This requires analyzing existing food systems to identify the changes needed to support the diversity of foods needed for human health while minimizing environmental impacts and supporting local cultures and livelihoods (FAO \& WHO, 2019). Policy coordination across sectors and scales is key so that the effects of policies on different facets of sustainability can be assessed and alignment in food system goals and strategies can be achieved (FAO \& WHO, 2019). In what follows, I look at the example of Lake Superior to explore the connections among sustainable diets and fisheries policy in this region.

Sustainable diets and fisheries: The case of Lake Superior

Lake Superior (Anishinabe Gichgamiing in Anishinaabemowin) is the largest and northernmost of the five Great Lakes of North America. It is the traditional homeland of the Anishinaabe peoples, including people known as Algonquin, Chippewa, Ojibwe, Mississauga, Potawatomi and Ottawa or Odawa (Bohaker, 2006). Jurisdictionally, Lake Superior is divided among the Canadian and U.S. federal governments, the Canadian province of Ontario, three U.S. states, and the traditional territories of approximately 120 First Nations and Indian tribes.

This piece focuses on the Canadian waters of Lake Superior. The Lake is closely tied to the economy and society of the surrounding region, including for drinking water, recreation, transportation, and food. First Nations have relied on Lake Superior fisheries for food and trade long before contact with European settlers and are increasingly asserting their rights to fish. The Lake supports a diversity of wildlife including over 30 native species of fish (Lake Superior Lakewide Action and Management Plan - Superior Work Group, 2013; Minnesota Sea Grant, 2014). 
For much of the twentieth century, a combination of overfishing, resource development, and commercial trade placed pressure on Lake Superior fisheries.

While there is still stress on the ecosystem, fish populations in Lake Superior have begun to recover since the 1980 s mainly due to government-led efforts to enhance water quality and control invasive species (Lowitt. Levkoe, \& Nelson, 2019, 2019; Spooner, 2014). In addition to efforts by provincial, federal, and Indigenous governments, trans-national bodies were established to deal with environmental and fisheries management concerns including the International Joint Commission and the Great Lakes Fishery Commission.

Today, Lake Superior contains commercial, recreational, and Indigenous fisheries. Fish is a culturally appropriate food in the region in which fresh meats and vegetables have traditionally been less available (Ontario Nature, 2014). The main commercial catches are lake whitefish, lake herring, and lake trout. While some fish stays within the region (particularly on northeastern Lake Superior where a sizeable Indigenous fishery supports household and regional markets), much of the catch from Canadian waters is exported to markets in the United States (Lowitt et al., 2019a). Over the last several decades, processing and infrastructure along the Ontario shore of Lake Superior has become more consolidated while fish harvesters receive prices for fish that generally do not keep up with increasing costs for fishing inputs, licensing, and quota (Lowitt et al., 2019a). This makes it particularly pressing to understand how fisheries policy might be reoriented in support of sustainable diets that can better meet regional food system needs.

Table 1 provides an overview of the key public policies and legislation governing Lake Superior fisheries. From a sustainable diet lens, this includes agencies and associated policy and legislation across the fisheries-based food system from harvesting and management to consumption. Key policies and legislative frameworks were identified through an analysis of websites of provincial, federal, and Indigenous organizations and governments and reading literature. The table is organized according to level of jurisdiction (trans-national, federal, provincial) with the final column summarizing the links to sustainable diets based on a document review. This analysis focuses primarily on settler policies and institutions; in terms of Indigenous fisheries, additional policies exist at a community level, but these tend to be unpublished and are not included in this paper. This is an area that warrants further case study research (see Lowitt, Levkoe, Lauzon, Ryan, \& Sayers,2019). 
Table 1: Fisheries legislation/policy and links to sustainable diets

\begin{tabular}{|c|c|c|c|}
\hline Agency & $\begin{array}{l}\text { Policy/legislation/plans/ } \\
\text { guidance }\end{array}$ & Purpose & Link to sustainable diets \\
\hline \multicolumn{4}{|l|}{ TRANSNATIONAL } \\
\hline $\begin{array}{l}\text { Great Lakes Fishery } \\
\text { Commission (Binational) }\end{array}$ & $\begin{array}{l}\text { Joint Strategic Plan for the } \\
\text { Management of Great } \\
\underline{\text { Lakes Fisheries }}\end{array}$ & $\begin{array}{l}\text { A Plan to ensure } \\
\text { coordinated action among } \\
\text { fisheries management } \\
\text { agencies across Canada / } \\
\text { U.S. management agencies. }\end{array}$ & $\begin{array}{l}\text { Recognizes wholesome food } \\
\text { as a social benefit tied to } \\
\text { fisheries. }\end{array}$ \\
\hline $\begin{array}{l}\text { International Joint } \\
\text { Commission (Binational) }\end{array}$ & $\begin{array}{l}\text { Great Lakes Water Quality } \\
\text { Agreement }\end{array}$ & $\begin{array}{l}\text { A framework for binational } \\
\text { consultation and action to } \\
\text { restore, protect and } \\
\text { enhance the water quality } \\
\text { of the Great Lakes and } \\
\text { promote the ecological } \\
\text { health of the basin. }\end{array}$ & $\begin{array}{l}\text { Asserts that the Great Lakes } \\
\text { should be free of pollutants } \\
\text { harmful to human health, } \\
\text { including from fish } \\
\text { consumption. }\end{array}$ \\
\hline $\begin{array}{l}\text { Tribal and First Nation } \\
\text { signatories }\end{array}$ & $\begin{array}{l}\text { Tribal and First Nations } \\
\text { Great Lakes Water Accord }\end{array}$ & $\begin{array}{l}\text { To assert that any } \\
\text { government effort to } \\
\text { protect the Great Lakes } \\
\text { must involve full } \\
\text { participation by Tribes and } \\
\text { First Nation who also agree } \\
\text { to work together to secure } \\
\text { a healthy future for the } \\
\text { Great Lakes. }\end{array}$ & $\begin{array}{l}\text { No specific mention of food } \\
\text { systems; however, } \\
\text { recognizes the health of the } \\
\text { Great Lakes ecosystem as } \\
\text { interconnected with } \\
\text { Indigenous wellbeing and } \\
\text { self-determination. }\end{array}$ \\
\hline \multicolumn{4}{|l|}{ FEDERAL } \\
\hline $\begin{array}{l}\text { Aboriginal and Treaty } \\
\text { rights }\end{array}$ & $\begin{array}{l}\text { Aboriginal and Treaty rights } \\
\text { are affirmed in Section } 35 \\
\text { of the Constitution Act, } \\
1982 . \\
\text { The main Treaties in the } \\
\text { Lake Superior region are } \\
\text { the Robinson Treaties and } \\
\underline{\text { Treaty } 9 .}\end{array}$ & $\begin{array}{l}\text { Lay out Nation to Nation } \\
\text { relationships and the } \\
\text { fiduciary responsibility of } \\
\text { the Crown. }\end{array}$ & $\begin{array}{l}\text { First Nations are asserting } \\
\text { Aboriginal and Treaty rights } \\
\text { to fish for subsistence and } \\
\text { commercial use. }\end{array}$ \\
\hline $\begin{array}{l}\text { Fisheries and Oceans } \\
\text { Canada }\end{array}$ & $\underline{\text { Canada Fisheries Act }}$ & $\begin{array}{l}\text { Provide a framework for the } \\
\text { proper management of } \\
\text { fisheries. First established in } \\
1867 \text {. Delegates authority } \\
\text { to manage inland fisheries } \\
\text { to the provinces. }\end{array}$ & $\begin{array}{l}\text { No specific mention of food } \\
\text { systems; however, social, } \\
\text { economic, and cultural } \\
\text { factors are included as } \\
\text { considerations for decision- } \\
\text { making. }\end{array}$ \\
\hline $\begin{array}{l}\text { Canadian Food Inspection } \\
\text { Agency }\end{array}$ & $\begin{array}{l}\text { Fish Inspection Regulations } \\
\text { (under the Fish Inspection } \\
\text { Act) }\end{array}$ & $\begin{array}{l}\text { Set standards for } \\
\text { acceptable quality, safety } \\
\text { and identity of fish and }\end{array}$ & $\begin{array}{l}\text { Concerned with the quality, } \\
\text { safety, and labelling of fish } \\
\text { for consumption. }\end{array}$ \\
\hline
\end{tabular}




\begin{tabular}{|c|c|c|c|}
\hline & & $\begin{array}{l}\text { seafood products. Applies } \\
\text { to fish processed in federal } \\
\text { establishments for } \\
\text { interprovincial or export } \\
\text { trade or that are imported } \\
\text { into Canada. }\end{array}$ & \\
\hline & $\begin{array}{l}\text { Food and Drugs } \\
\text { Regulations (under the } \\
\text { Food and Drugs) Act }\end{array}$ & $\begin{array}{l}\text { Enforce health and safety } \\
\text { standards for all food and } \\
\text { drugs. Applies to fish and } \\
\text { fish products destined for } \\
\text { inter and intra provincial } \\
\text { trade. }\end{array}$ & $\begin{array}{l}\text { Concerned with nutrition, } \\
\text { health, and safety of food, } \\
\text { including fish. }\end{array}$ \\
\hline & $\frac{\text { Safe Food for Canadians }}{\underline{\text { Act }}}$ & $\begin{array}{l}\text { Enforce labelling } \\
\text { requirements for } \\
\text { prepackaged consumer } \\
\text { goods. Applies to fish and } \\
\text { fish products import, } \\
\text { export, and inter provincial } \\
\text { trade. }\end{array}$ & $\begin{array}{l}\text { Concerned with appropriate } \\
\text { food labelling, including for } \\
\text { fish. }\end{array}$ \\
\hline Health Canada & $\underline{\text { Canada's Food Guides }}$ & $\begin{array}{l}\text { Provide recommendations } \\
\text { on how much and what } \\
\text { types of food should be } \\
\text { eaten as part of a healthy } \\
\text { diet. }\end{array}$ & $\begin{array}{l}\text { Concerned with helping } \\
\text { Canadians make healthy } \\
\text { food choices, including fish. } \\
\text { Does not consider } \\
\text { Indigenous diets. }\end{array}$ \\
\hline \multicolumn{4}{|l|}{ PROVINCIAL } \\
\hline $\begin{array}{l}\text { Ontario Ministry of } \\
\text { Natural Resources and } \\
\text { Fisheries }\end{array}$ & $\begin{array}{l}\text { Ontario Fishery Regulations } \\
\text { (annexed to the federal } \\
\text { Fisheries Act). }\end{array}$ & $\begin{array}{l}\text { Focus on the sustainable } \\
\text { conservation and harvesting } \\
\text { of fish. First established } \\
1898 .\end{array}$ & $\begin{array}{l}\text { No mention of food but } \\
\text { regulations may influence } \\
\text { fish access and availability. }\end{array}$ \\
\hline $\begin{array}{l}\text { Ontario Ministry of } \\
\text { Natural Resources and } \\
\text { Fisheries }\end{array}$ & $\begin{array}{l}\text { Ontario Provincial Fish } \\
\underline{\text { Strategy: Fish for the future }}\end{array}$ & $\begin{array}{l}\text { Strategy for managing } \\
\text { Ontario's commercial, } \\
\text { recreational, and Aboriginal } \\
\text { fisheries (under the } \\
\text { authority of the Ontario } \\
\text { Fishery Regulations). }\end{array}$ & $\begin{array}{l}\text { Recognizes fishing as an } \\
\text { activity that supports the } \\
\text { nutritional needs of } \\
\text { communities and individuals } \\
\text { in Ontario. }\end{array}$ \\
\hline $\begin{array}{l}\text { Ontario Ministry of } \\
\text { Natural Resources and } \\
\text { Fisheries }\end{array}$ & $\begin{array}{l}\text { Regulation } 664 \text { Fish } \\
\text { Licensing (under the Fish } \\
\text { and Wildlife Conservation } \\
\underline{\text { Act) }}\end{array}$ & $\begin{array}{l}\text { Sets licensing requirements } \\
\text { for commercial and } \\
\text { recreational fishing. }\end{array}$ & $\begin{array}{l}\text { No mention of food but lays } \\
\text { out licensing requirements } \\
\text { that may influence access to } \\
\text { fish for food. }\end{array}$ \\
\hline $\begin{array}{l}\text { Ontario Ministry of } \\
\text { Natural Resources and } \\
\text { Fisheries }\end{array}$ & Ontario Fish Inspection Act & $\begin{array}{l}\text { Set the standards of fish } \\
\text { processing. Applies to non- } \\
\text { federally registered fish } \\
\text { processors distributing } \\
\text { within the province. }\end{array}$ & $\begin{array}{l}\text { Concerned with ensuring } \\
\text { safe fish for human } \\
\text { consumption. }\end{array}$ \\
\hline $\begin{array}{l}\text { Ontario Ministry of } \\
\text { Agriculture Food and }\end{array}$ & Food Safety and Quality Act & $\begin{array}{l}\text { Establish standards for food } \\
\text { safety and quality. }\end{array}$ & $\begin{array}{l}\text { Fish regulated as a food } \\
\text { under this Act. }\end{array}$ \\
\hline
\end{tabular}




\begin{tabular}{|l|l|l|l|}
\hline Rural Affairs (provincial) & & & \\
\hline $\begin{array}{l}\text { Ministry of Health and } \\
\text { Long-Term Care }\end{array}$ & $\begin{array}{l}\text { Health Protection and } \\
\text { Promotion Act }\end{array}$ & $\begin{array}{l}\text { To promote and protect the } \\
\text { health of people in Ontario. }\end{array}$ & $\begin{array}{l}\text { Concerned with multiple } \\
\text { facets of public health, } \\
\text { including upholding public } \\
\text { health standards in food } \\
\text { premises and reducing } \\
\text { chronic disease. }\end{array}$ \\
\hline $\begin{array}{l}\text { Ministry of the } \\
\text { Environment, } \\
\text { Conservation, and Parks }\end{array}$ & $\begin{array}{l}\text { Eating Ontario Fish } \\
\text { Guidelines }\end{array}$ & $\begin{array}{l}\text { Offer consumption advice } \\
\text { for fish from Ontario lakes } \\
\text { and rivers based on } \\
\text { contaminant levels for } \\
\text { fisheries. }\end{array}$ & $\begin{array}{l}\text { Concerned with safe fish } \\
\text { consumption. }\end{array}$ \\
\hline
\end{tabular}

As seen in Table 1, numerous policies and legislative frameworks, located in various agencies and at different levels of jurisdiction, impact fisheries and their role in sustainable diets. Some of these policies directly influence fisheries in the region (e.g. setting regulations for harvesting) while others, such as policies for public health, are more distal such as through influencing consumer purchasing and utilization of fish. Overall, these can be placed into two broad categories: those dealing with fisheries management (including regulations for the conservation and harvesting of fish) and those dealing with some aspect of fish for consumption after it has been landed, including safety, nutrition, quality, and labelling.

The Ontario Ministry of Natural Resources and Forestry (OMNRF) is the settler government agency with primary authority for fisheries management on Lake Superior. Ontario is expected to coordinate its activities with bi-national bodies, such as the Great Lakes Fishery Commission, to address transborder issues. Aboriginal and Treaty rights add another layer to this jurisdictional complexity. Many fisheries management policies make some reference to food. For example, the Ontario Provincial Fish Strategy identifies nutritional needs for individuals and communities in Ontario as a priority; it also identifies a trend towards healthy and local food as an opportunity for engaging a greater diversity of people with an interest in fisheries and their management. Likewise, transnational agreements, such as the Joint Strategic Plan for the Management of Great Lake Fisheries and the Great Lakes Water Quality Agreement recognizes a key social benefit tied to fisheries is as a source of food. Further, many of these policies emphasize sustainable fisheries, in terms of ecosystem health and ensuring that Lake Superior fisheries are sufficiently protected for future generations to enjoy.

However, while management policies may refer to food, the emphasis is on managing fish for conservation and economic benefit, with a food systems perspective missing. As evidence of this, there is no reference in management policies to the downstream stages and policies associated with fish consumption. Here, a different set of policies and legislative frameworks take over including provincial and federal ministries in the areas of health, food, and agriculture dealing with various aspects of processing, safety, quality, labelling, and health. 
These policies conversely operate in isolation from the management and ecological context of fisheries. An exception is the Eating Ontario Fish Guidelines for recreational fishers which provides information about fishing locations, types of fish, contaminant levels, and consumption recommendations.

The lack of integration between fisheries management policies and those dealing with fish for consumption has been identified in other studies of North American fisheries (see Love et al., 2017) and addressing this is key to retooling policy for sustainable diets. Because of this gap, food systems connections are often overlooked or, worse, policies may function at crosspurposes. A good example is the impact of harvesting regulations on access to fish for food. Lake Superior commercial fisheries are managed using Individual Transfer Quotas (ITQs) ${ }^{1}$ under the Ontario Fishery Regulations. While ITQs have been widely critiqued for concentrating wealth in fisheries (Pinkerton, 2013), there is also evidence in the case of Lake Superior that ITQs are leading to nutritious fish being shipped out of the region into large markets in the US where it is used as low-quality protein and processed into gefilte fish (Lowitt et al., 2019a). Despite reference to "wholesome food" as a benefit to Ontarians in the Provincial Fish Strategy, such benefits are unlikely to be realized until management policies are assessed to consider their impacts on downstream stages of the food system.

Conversely, policies related to health and fish consumption should operate in closer coordination with fisheries management objectives. For example, Canada's Food Guide does not offer advice on the origin of foods to eat, simply saying "refer to food labels." Labelling requirements for fish destined for export and inter-provincial trade are set by federal agencies and by the province of Ontario for fish sold within the province. In both cases, the geographic origin of the fish and method of harvest is not required information making it difficult for consumers to be fully informed about the fish they are eating (Roebuck et al., 2017). In the Lake Superior region, some direct fish marketing businesses have emerged to meet the consumer demand for local, traceable, and fresh fish. However, interviews undertaken with Lake Superior fish processors and retailers as part of my previous research in the region (see Lowitt et al., 2019a), suggest that navigating the disparate agencies involved in the fisheries-based food system is a challenge and that there is a lack of policy supports and guidance available to new fisheries businesses.

In addition to addressing the gap between policies dealing with fisheries management and fish consumption, another priority for sustainable diets linked to fisheries needs to be reconciliation with Indigenous communities. According to the Ontario Provincial Fish Strategy, Indigenous people do not need a license for fishing for food, social, or ceremonial purposes within their territories; Indigenous commercial fisheries receive quota allocations in accordance with the province's interpretation of case law.

\footnotetext{
${ }^{1}$ ITQs are a market-based allocation tool that enables fisheries managers to allocate pre-determined shares of the Total Allowable Catch (TAC) to individual quota owners who can transfer them to others.
} 
However, many First Nations challenge the province's view of underlying management control of fisheries, asserting inherent Aboriginal and Treaty rights ${ }^{2}$ to fish and the pursuit of fishing as fundamental to self-determination and food sovereignty (Lowitt et al., 2019b). Governments and trans-national bodies across the Great Lakes, including Lake Superior, have been critiqued for not upholding Treaty relationships and treating First Nations as stakeholders within governance forums (Norman, 2015). For example, no First Nation has been invited to sign the Joint Strategic Plan for the Management of Great Lakes Fisheries, the main multi-jurisdictional agreement for basin-wide fisheries management. The Tribal and First Nations Great Lakes Water Accord is a response to this inequity in existing governance structures. Policy for sustainable diets in the region needs to uphold Indigenous rights and recognize the unique cultural, spiritual, and ecological relationships that surround fisheries and their roles in sustainable diets within Indigenous communities (Kuhnlein \& Humphries, 2017; Lowitt et al., 2019b). Further, Indigenous governance rooted in principles of interconnection among people and ecosystems may likewise help address the policy gaps between fisheries management,consumption, and health (Cooke et al., 2020; Lowitt et al., 2019b).

\section{Conclusion}

In conclusion, this perspective piece has sought to identify opportunities for linking fisheries policy to a consideration of sustainable diets in the Lake Superior region. I suggest this will depend on forming new collaborations across fisheries and the broader food system, including fisheries managers, public health, and food and agriculture agencies working together to address systems-level interactions and issues. It also requires settler laws and policies recognizing and supporting Indigenous fisheries governance that may contribute to sustainable diets within those communities. Lastly, interdisciplinary research spanning fisheries, social science, and health will be important to providing a more integrative understanding of fisheries, including their ecological and socio-cultural aspects, to inform future policy for sustainable diets in the region.

Acknowledgements: I would like to acknowledge conceptual input from the Food: Locally Embedded Globally Engaged (FLEdGE) research team, as well as Charles Levkoe for his contributions to our previous research together which has informed this article. I also acknowledge financial support from the Social Sciences and Humanities Research Council of Canada.

\footnotetext{
${ }^{2}$ Inherent rights do not arise from any particular law or Treaty but are pre-existing rights believed to be granted to Indigenous people by the Creator (Sanderson, 2017). They are distinct from but related to Aboriginal and Treaty rights as affirmed in the Constitution of Canada.
} 


\section{References}

Berkes, F (2010). Shifting perspectives on resource management: Resilience and the reconceptualization of 'natural resources' and 'management.' MAST, 9(1) 13-40.

Bohaker. H. (2006). Nindoodemag: Anishinaabe Identities in the Eastern Great Lakes Region, 1600 to 1900. [Doctoral dissertation, University of Toronto]. Library and Archives Canada.

Burlingame, B., Dernini, S., \& FAO. (2010). Sustainable diets and biodiversity: Directions and solutions for policy, research and action. Rome.

http://www.fao.org/3/i3004e/i3004e00.htm.

Clapp, J. (2018). Mega mergers on the menu: Corporate concentration and the politics of sustainability in the global food system. Global Environmental Politics, 18(3), 12-33.

Cooke, S., Nguyen, V.M., Chapman, J.M., Reid, A.J., Landsman, S.J., Young, N., Hinch, S.G., Schott, S., Mandrak, N.E., Semeniuk, C.A.D. (2020). Knowledge co-production: A pathway to effective fisheries management, conservation, and governance. Fisheries Magazine. https://doi.org/10.1002/fsh.10512.

FAO, \& WHO. (2019). Sustainable healthy diets - Guiding principles. Rome. http://www.fao.org/3/ca6640en/ca6640en.pdf.

FAO. (2015). Voluntary guidelines for securing sustainable small-scale fisheries in the context of food security and poverty eradication. Retrieved from http://www.fao.org/3/ai4356en.pdf.

Fisher, B., Naidoo, R., Guernier, J., Johnson, K., Mullins, D., Robinson, D., \& Allison, E. (2017). Integrating fisheries and agricultural programs for food security. Agriculture \& Food Security, 6(1). https://doi.org/10.1186/s40066-016-0078-0.

Hawkes, C., Friel, S., Lobstein, T., \& Lang, T. (2012). Linking agricultural policies with obesity and noncommunicable diseases: A new perspective for a globalising world. Food Policy, 37(3), 343-353.

Hendrickson, M. (2014). Resilience in a concentrated and consolidated food system. Journal of Environmental Studies and Sciences, 5(3), 418-431. https://doi.org/10.1007/s13412-015$\underline{0292-2}$

Lake Superior lakewide action and management plan 2015-2019. (2016). The Lake Superior Partnership. Retrieved from https://binational.net/wpcontent/uploads/2016/09/Lake\%20Superior\%20LAMP\%202015-2019.pdf

Kuhnlein, H. V. \& Humphries, M. M. (2017) Traditional animal foods of Indigenous peoples of Northern North America. Montreal, Centre for Indigenous Peoples' Nutrition and Environment. 
Loring, P., Gerlach, S., \& Harrison, H. (2013). Seafood as local food: food security and locally caught seafood on Alaska's Kenai Peninsula. Journal of Agriculture Food Systems and Community Development, 3(3), 13-30.

Loring, P., Fazzino, D. Agapito, M., Chuenpagdee, R., Gannon, G., \& Isaacs. M. (2019). Fish and food security in small-scale fisheries. In R. Chuenpagdee, \& S. Jentoft (Eds.), Transdisciplinarity for Small-Scale Fisheries Governance (pp.55-73). Springer.

Love, D., da Silva, P., Olson, J., Fry, J., \& Clay, P. (2017). Fisheries, food, and health in the USA: the importance of aligning fisheries and health policies. Agriculture and Food Security, 6(16). https://doi.org/10.1186/s40066-017-0093-9.

Lowitt, K., Levkoe, C., \& Nelson, C. (2019). Where are the fish? Using a fish as food framework to explore the Thunder Bay Area fisheries. Northern Review, 49, 39-65.

Lowitt, K., Levkoe, C., Lauzon, R., Ryan, K. \& Sayers, D. (2019). Indigenous self-determination and food sovereignty through fisheries governance in the Great Lakes Region. In P. Andrée, J. Clark, C. Levkoe, \& K. Lowitt. (Eds.), Civil Society and Social Movements in Food System Governance (pp. 145-163). Routledge Press.

Lowitt, K. (2013). Examining fisheries contributions to community food security: Findings from a household seafood consumption survey on the west coast of Newfoundland. Journal of Hunger and Environmental Nutrition, 8(2), 221-241.

Minnesota Sea Grant. (2014, October 23). Lake Superior's fish species. Retrieved from http://www.seagrant.umn.edu/fisheries/superior_fish_species

Norman, E. (2015). Governing transboundary waters: Canada, the United States, and Indigenous communities. Routledge Press.

Ontario Nature. (2014). Beyond the field: The value of forest and freshwater foods in Northern Ontario. Retrieved from https://ontarionature.org/wpcontent/uploads/2017/10/beyond the fields.pdf.

Pinkerton, E. (2013). Alternatives to ITQs in equity-efficiency-effectiveness trade-offs: How the lay-up system spread effort in the BC halibut fishery. Marine Policy, 42, 5-13. doi.org/10.1016/j.marpol.2013.01.010.

Roebuck, K., Turlo, C., Fuller, S., \& Wallace, S. (2017). Canadians eating in the dark: A report card of international seafood labelling requirements. SeaChoice. Retrieved from https://www.seachoice.org/wp-content/uploads/2017/03/Seafood-Labelling-ReportOnline.pdf.

Sanderson, S. (2017) Constitution Act 1982: implementation of sections 35(1) and 35 (2). FSIN Office of the Senate. Available at: 
https://sencanada.ca/content/sen/committee/421/APPA/Briefs/ConstitutionAct_2017-0919 e.pdf.

Seto, K., \& Fiorella, K. (2017). From sea to plate: The role of fish in a sustainable diet. Frontiers in Marine Science. https://doi.org/10.3389/fmars.2017.00074

Spooner, E. (2014). Monterey Bay Aquarium seafood watch. Retrieved from http://seafood.ocean.org/wp-content/uploads/2016/10/Lake-Superior-lakefish.pdf

Tansey, G., \& Worsley, T. (1995). The food system: A guide. Earthscan Publications Ltd.

Willett, W., Rockström, J., Loken, J., Springmann, M., Lang, T., Vermeulen, S., Garnett, S., Tilman, D., DeClerck, F., Wood, A., Jonell, M., Clark, M., Gordon, L.J., Fanzo, J., Hawkes, C., Zurayk, R., Rivera, J.A., De Vries, W., Sibanda, L.M., Afshin, A... Murray, C.J.L. (2019). Food in the Anthropocene: the EAT-Lancet Commission on healthy diets from sustainable food systems. The Lancet Commissions, 393(10170), 447-492. https://doi.org/10.1016/S0140-6736(18)31788-4. 